\title{
Agricultural Banks: Causes of Failures and the Condition of Survivors
}

\author{
Michael T. Belongia and R. Alton Gilbert
}

$\mathbf{T}$

HE number of bank failures has risen sharply in recent years. From 1943 to 1981 , no more than 17 commercial banks ever failed in a single year. Since 1982, when 34 banks failed, the number of failures has risen each year, reaching 144 in 1986 . The failed banks have been concentrated increasingly among small, rural banks in general and agricultural banks in particular. In the years 1984 through 1986, about half of the 340 failed banks were agricultural banks, those with ratios of agricultural loans to total loans above the unweighted national average. Agricultural banks make up about one-third of all banks.'

Although the current downturn in the farm economy has been both extensive and protracted, the number of agricultural bank failures in recent years represents only a small percentage of all agricultural banks. This article examines the financial condition of both the surviving and failed agricultural banks to determine why some banks have failed while most have survived. The results have important implicaw tions for the ability of banks in rural areas to continue to finance local farm business.

\footnotetext{
Michael $T$. Belongia is a senior economist and $R$. Atton Gilbert is an assistant vice president at the Federal Reserve Bank of St. Louis. Paut Crosby provided research assistance.

in recent years, the unweighted average ratio of agricutural loans to total loans for all commercial banks has been around 17 percent. This paper uses 17 percent throughout as the criterion for identifying agricultural banks. Melichar (1987) reports that, on December 31 , 1986 , there were 4,700 banks that had ratios of agricultural loans to total loans above the unweighted national average of 15.7 percent.
}

\section{REASONS FOR AGRICULTURAL BANK FAILURES}

The rise in failures among agricultural banks reflects the continuing financial distress of farmers in the 1980s. Although agriculture has been a declining industry for some time, its downturn since 1981 has been unusually abrupt and severe. The financial distress in the agricultural sector has its roots in the accumulation of farm debt in the 1970s. As chart 1 shows, the price of farmland and the value of farm debt rose sharply and persistently throughout the 1970s.

The growth of farm income, however, did not keep pace with the rise in farm debt. Some farmers borrowed heavily to purchase higher priced land in anticipation of future appreciation; others borrowed to offset their declining real returns to investments in farming and to finance current consumption. These trends left farmers with heavy debt burdens as they entered the $1980 \mathrm{~s}$.

In 1981, these trends changed abruptly. A severe and protracted worldwide recession, which lowered foreign incomes sharply, reduced export sales of U.S. farm products and real net farm income. At the same time, the rate of inflation and expectations of future

${ }^{2}$ See Belongia and Gilbert (1985) and Belongia (1986) for more detail on changes in farm prices, income and asset values since 1981. Belongia and Carraro (1985) discuss the deterioration in porttolio quality for major farm lenders over the same period. 
Chart 1

\section{Farm Land Values and Farm Debt}

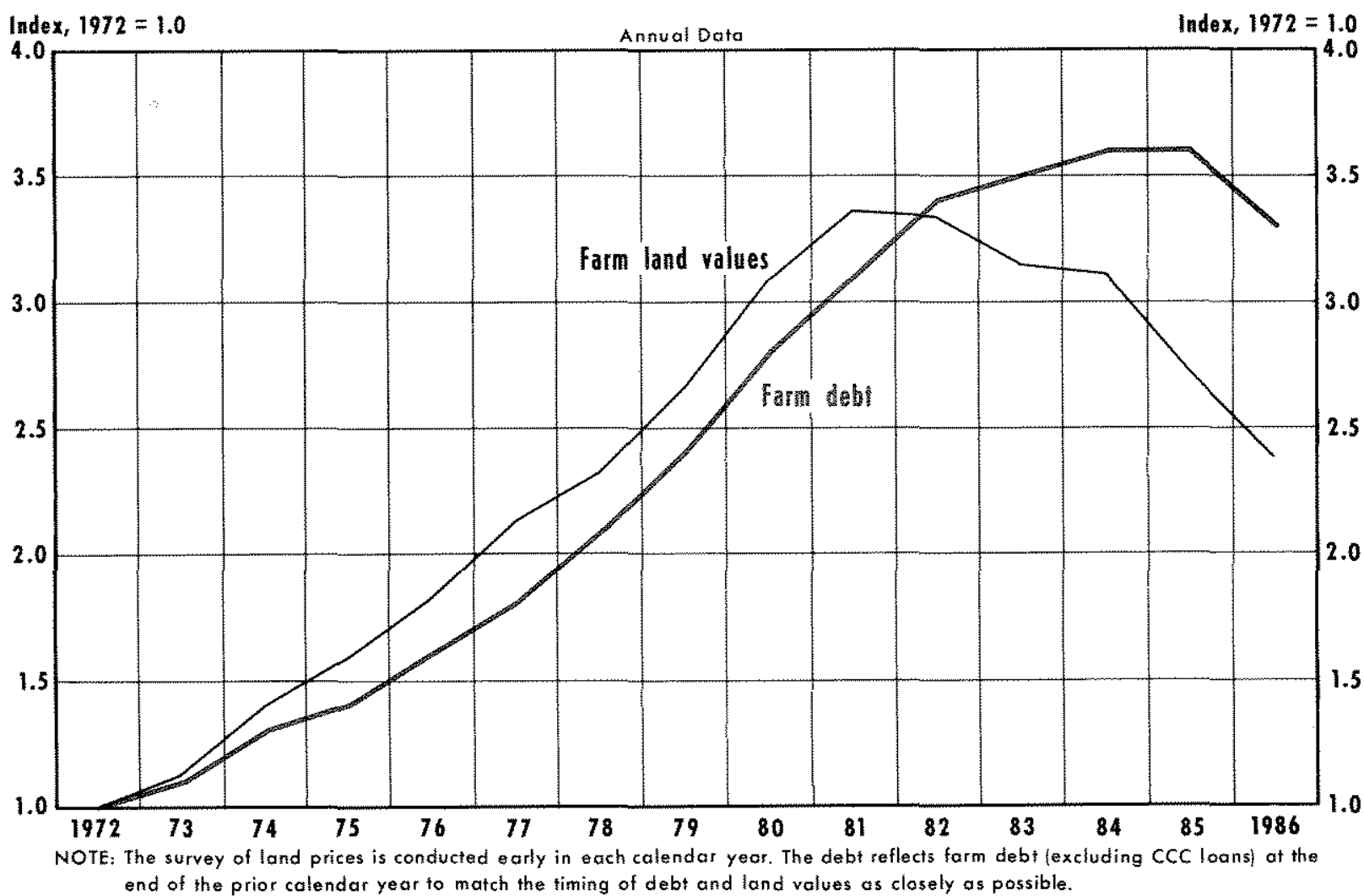

inflation suddenly were reduced, lessening the demand for assets like farmland, which are viewed as hedges against inflation. With declining retums to the business of farming and diminished expectations of appreciation in farmland prices, the demand for farmland fell and prices declined. Finally, the 1981 tax bill may have raised the real rate of interest which, in a standard model of asset prices, also would tend to reduce land prices, ${ }^{3}$

With lower export sales and lower income, many farmers could not generate sufficient cash flow to service their debts. Moreover, with land values declining sharply, farmers could not pay off their debts by selling their land. As a result, banks have recorded losses on loans to such farmers. The banks with relatively large losses have failed.

3See, for example, Holland (1984) for arguments and evidence on this issue.

${ }^{4}$ Estimates of farm debt unlkely to be repaid and the consequences of allowing different groups to bear the losses are found in Bullock (1985).

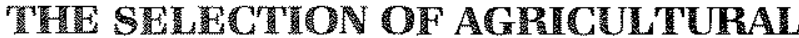

\section{BANKTIG DATA}

The analysis of banking data begins with the selection of counties in which agricultural banks failed between January 1, 1984, and December 9, 1986. From the set of all farm bank failures, many banks were deleted. For example, banks in states that permit bank branching beyond the county of a bank's headquarters were eliminated because income and balance sheet data are not available on the individual branches. Banks in other states were excluded because there were no failures of agricultural banks. The remaining sample includes counties in the 10 states listed in table 1.

Table 1 indicates the number of farm bank failures that occurred in the 10 states from 1984 through 1986 . To check for clustering of failures in particular regions of a state, the table also lists the number of counties in which farm bank failures occurred. As the table indicates, maltiple failures within a county during the 


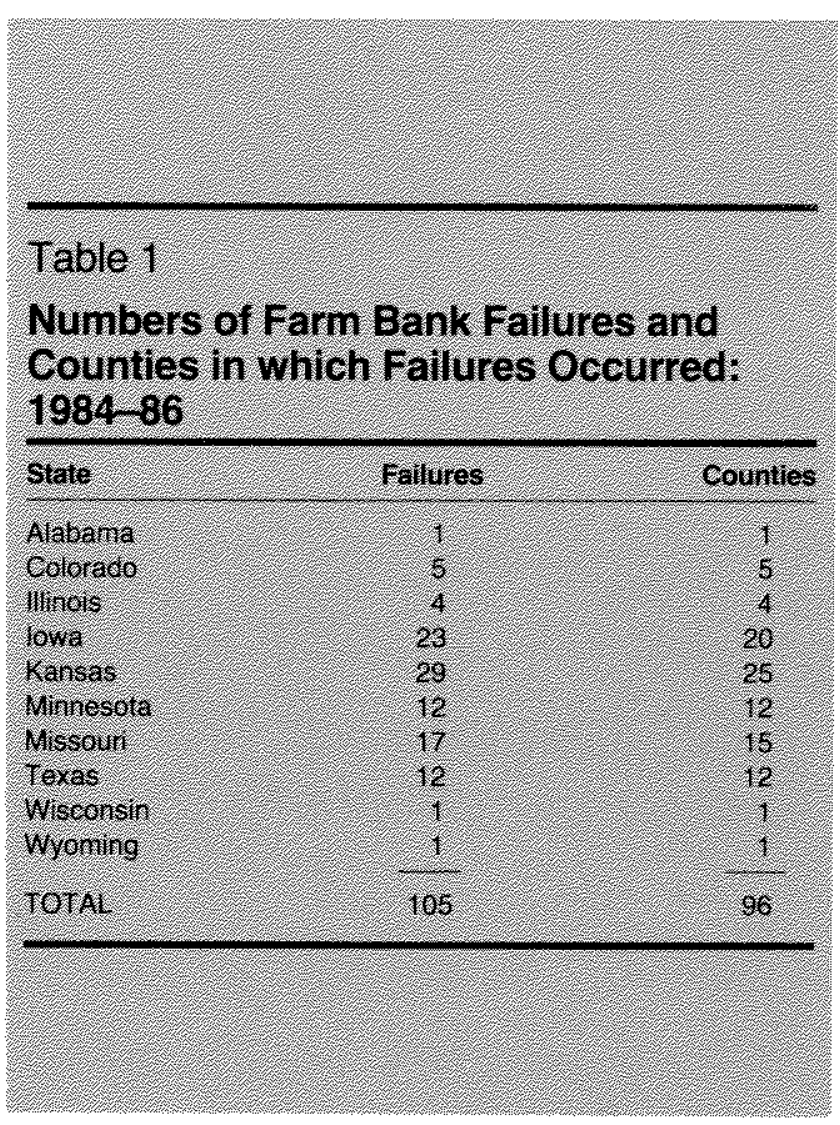

three-year period were limited to lowa, Kansas and Missouri. Even in these states, such failures were spread across nearly equal numbers of counties. Only two counties lone in lowa in 1985 and another in Kansas in 1986) experienced more than one bank failure in a single year.

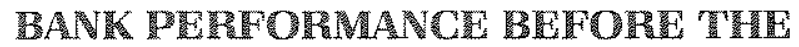 FARM SEGTOR DECHWE}

The next stage of the analysis compares the performance in 1981 of the agricultural banks that failed between 1984 and 1986 with that of agricultural banks in the same counties that had not failed as of June 1986. We then analyze the condition of the surviving agricultural banks in 1986.

There were 519 agricultural banks in June 1981 in the 96 counties identified in table $1 ; 105$ falled between 1984 and 1986, and 414 still were in operation as of June 1986. The first comparison assesses whether the banks that ultimately failed were in relatively good financial condition in 1981. If they were not, their failure may have been largely unrelated to the farm sector decline in recent years.
Table 2 presents several indicators of asset composition and financial performance for the failed and surviving banks. Loan and asser ratios are as of June 1981, whereas returns on equity (ROE) and total assets (ROA) are based on averages for the year $1981 .{ }^{5}$ In 1981 , the banks in these two groups appeared to be similarly able to absorb loan losses: they had comparable primary capital/assets ratios of 9.52 percent and 9.11 percent. Furthermore, returns on assets and equity were not significantly different, at the 5 percent level, for the two groups of banks. Thus, these banks generated similar earnings and had a similar capacity to absorb losses in the value of their assets.

Because discussions of the financial distress in the agricultural sector generally emphasize the effects of declining farmland prices, we might expect the agricultural banks that have failed to be among those with relatively high percentages of their loans secured by farm real estate. This, however, is not the case. Loans secured by farm real estate accounted for only 5 percent of total loans at the surviving banks in 1981 and only 4 percent of total loans at the banks that subsequently failed. While table 2 shows that the surviving banks invested smaller percentages of their loans in farm production loans not secured by farm real estate, the difference is statistically significant at only the 10 percent level.

As of June 1981, banks that failed had slightly higher ratios of commercial and industrial loans to total loans, but these ratios are not significantly different for the failed and surviving banks. The surviving banks had significantly higher ratios of nonfarm real estate loans to total loans than the faled banks. Thus, the reasons why some banks have failed while others have survived cannot be tied directly to the declines in real estate prices in rural areas.

Differences in the composition of investments indicate that, in June 1981, the banks that ultimately failed chose securities with higher default risk than the banks that have survived. The failed banks had higher

5Data for only 102 failed banks are presented because data for three banks identified as tailures could not be traced back to 1981. There also was a problem with the data for one solvent bank; thus, only 473 observations could be used.

Report of Condition data for June 30 are used to calculate loan and asset ratios because most farm loans are booked by this time of each year but are paid off in the third and fouth quarters. June 30 data thus avoid the problems of onititing some loans (as first-quarter data would do), loan repayments and end-of-year "window-dressing." Annual averages are used for ROE and BOA data, however, to avoid possible distortions from using what typically is a good quarter for eamings to calculate annualized rates of return. 


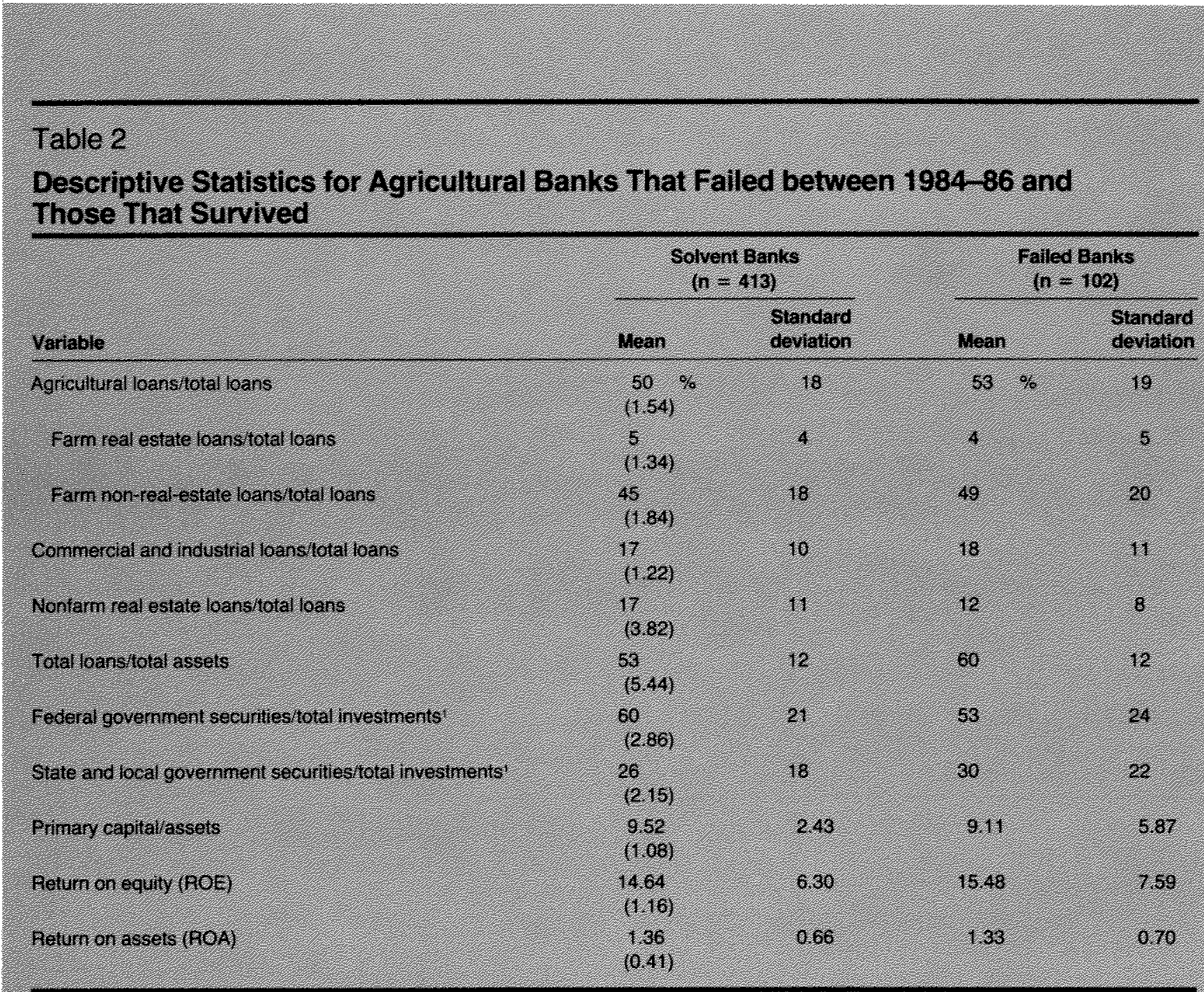

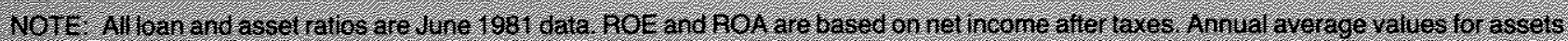

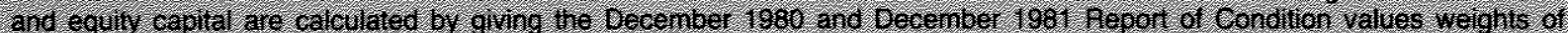

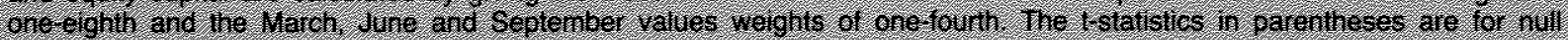

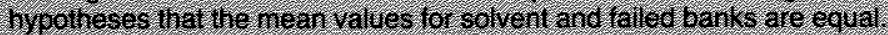

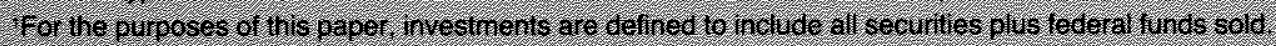

ratios of state and local government securities to total investments and lower ratios of federal government securities to total investments.

The difference between the ratios of total loans to total assets at failed and surviving banks yields the highest t-statistic. In June 1981, the ratio of loans to assets was 60 percent, on average, for the banks that failed, but only 53 percent for the surviving banks. Thus, the agricultural banks that have failed had relatively higher ratios of loans to assets in 1981 .

\section{CONTROLLHE FOR DRFERENCES TN LOCA ECONOMIC CONDITIONS}

Before attributing cause-and-effect to higher loan ratios and bank failure, however, it should be noted that this relationship might be spurious. For example, most failed banks could have been located in areas with stronger loan demand in 1981 and larger losses in subsequent years. Conversely, most surviving banks could be located in counties with lower loan demand 


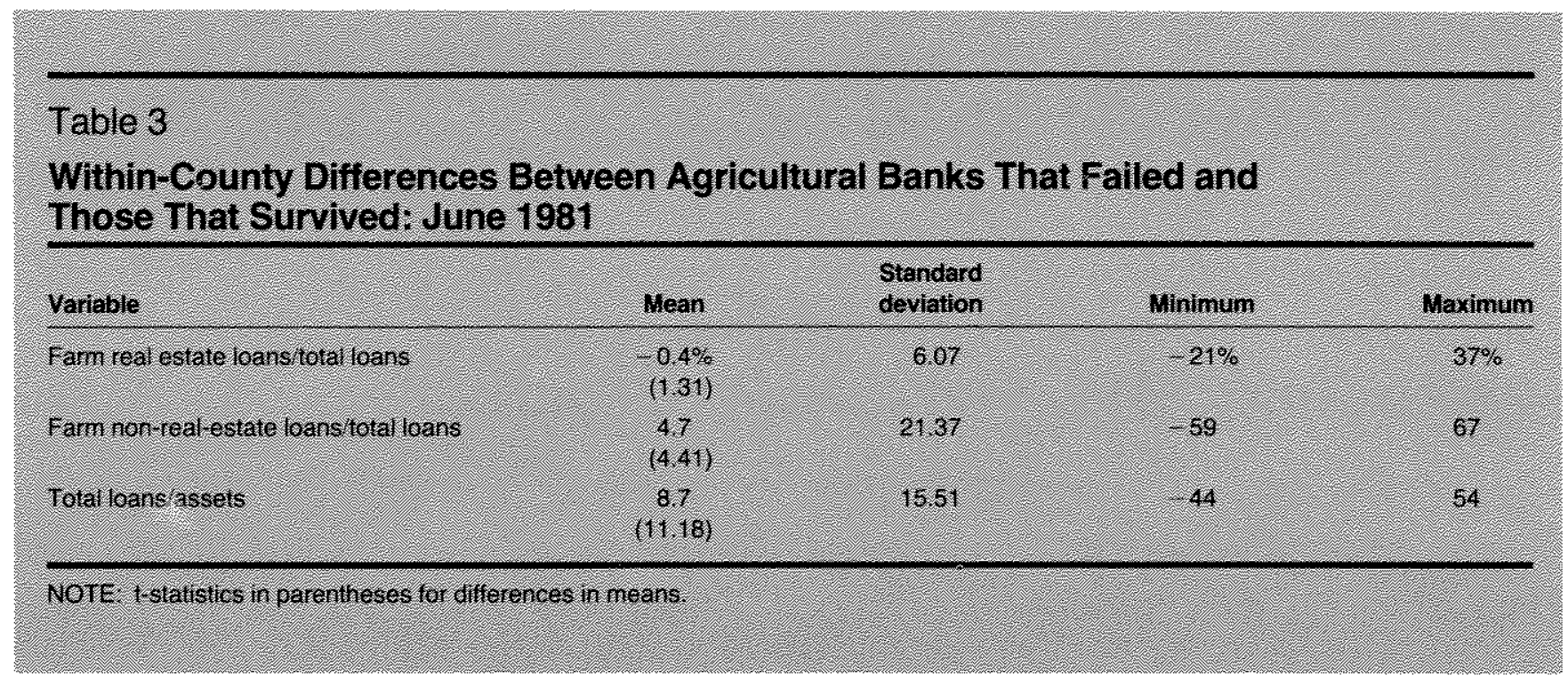

in 1981 and lower loss fates since then. A closer look at the data, controlling for the potential effects of local economic factors, is required to investigate this possibility.

Local influences on bank performance can be held constant in a variety of ways. One is to compare the loan ratios for June 1981 of each bank that subsequently failed with those of banks located in the same counties that survived. If the lower loan ratios at the surviving banks displayed in table 2 reflect differences in loan demand, the spreads between loan ratios at failed banks and surviving agricultural banks in the same counties will tend to be small and not signifcantly different from zero.

This, however, is not the case. The ratios of non-real estate farm loans to totall loans were about 5 percent* age points higher, on average, at the banks that subsequently failed than at the surviving banks in the same counties; this difference is statistically significant at the 5 percent level (see table 3 ). The banks that subsequently failed also had ratios of total loans to total assets that were almost 9 percentage points higher, on average, than the surviving banks located in the same counties. In confrast, differences between ratios of fam real estate loans to total loans were essentially zero numerically and not significant statistically.

Comparisons of failed and surviving banks located in the same counties sharpen rather than reduce the distinctions between the falled and surviving banks. The banks that faled had accepted greater risks than other banks in the same counties by investing higher percentages of their assets in loans generally and more of their loans in farm loans.
There also is evidence that the agricultural banks which maintained relatively high ratios of loans to assets tended to make poorer quality loans. Melichar found that, as of December 31, 1985, the banks with higher ratios of loans to deposits tended to have higher ratios of nonperforming loans to total loans. ${ }^{6}$ Thus, the distinction between the failed and surviving banks based on their ratios of loans to assets may reflect differences in loan quality as well as the risk inherent in operating banks with relatively high ratios of loans to assets.

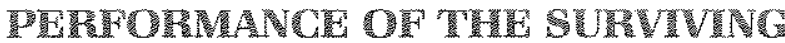 DAR}

Table 4 presents data for banks that were still in business as of year-end 1986; the smaller number of observations, 400, reflects problems with the data for some banks, which were deleted. Although still solvent, earnings at these surviving institutions declined substantially over the five-year period, as comparisons with the 1981 ROE and ROA figures indicate. Losses also led to a numerically small but statistically significant reduction in the average capital ratios of these institutions. The average capitalassets ratio of 8.94 percent in 1986, nonetheless, is substantially above regulatory guidelines for a minimum ratio of primary capital to total assets of 5.5 percent.

Table 4 also indicates reductions in the ratios of both agricultural loans to total loans and of total loans

\footnotetext{
Melichar (1986), pp. 445-46.

'See Gibert, Stone and Trebing (1985).
} 


\section{Table 4}

Descriptive Statistics for Solvent Banks: June 1981 and June $1986(n=400)$

\begin{tabular}{|c|c|c|c|c|}
\hline Variable & June $1081 \mathrm{vean}$ & June $1986 \mathrm{Neah}$ & Juno 1986 tinimun & Wune 1966 naxinum \\
\hline Agrigurural loans holat loans & $(1989 \%$ & $67.30 \%$ & $1.960 \%$ & $97.9 \%$ \\
\hline Tolal loarshassels & 56.50 & 4471 & 9.66 & 8226 \\
\hline Prinurs capitalessevs & $(8,52$ & & 2.96 & 23.49 \\
\hline Retum on equly fROE & 1,164 & 0006 & 90.96 & 32.86 \\
\hline Pelum on assets (Roh) & 1.36 & 020 & 662 & 37 \\
\hline
\end{tabular}

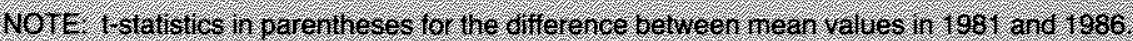

rol and RoA a ce anma average rates ol tetwin

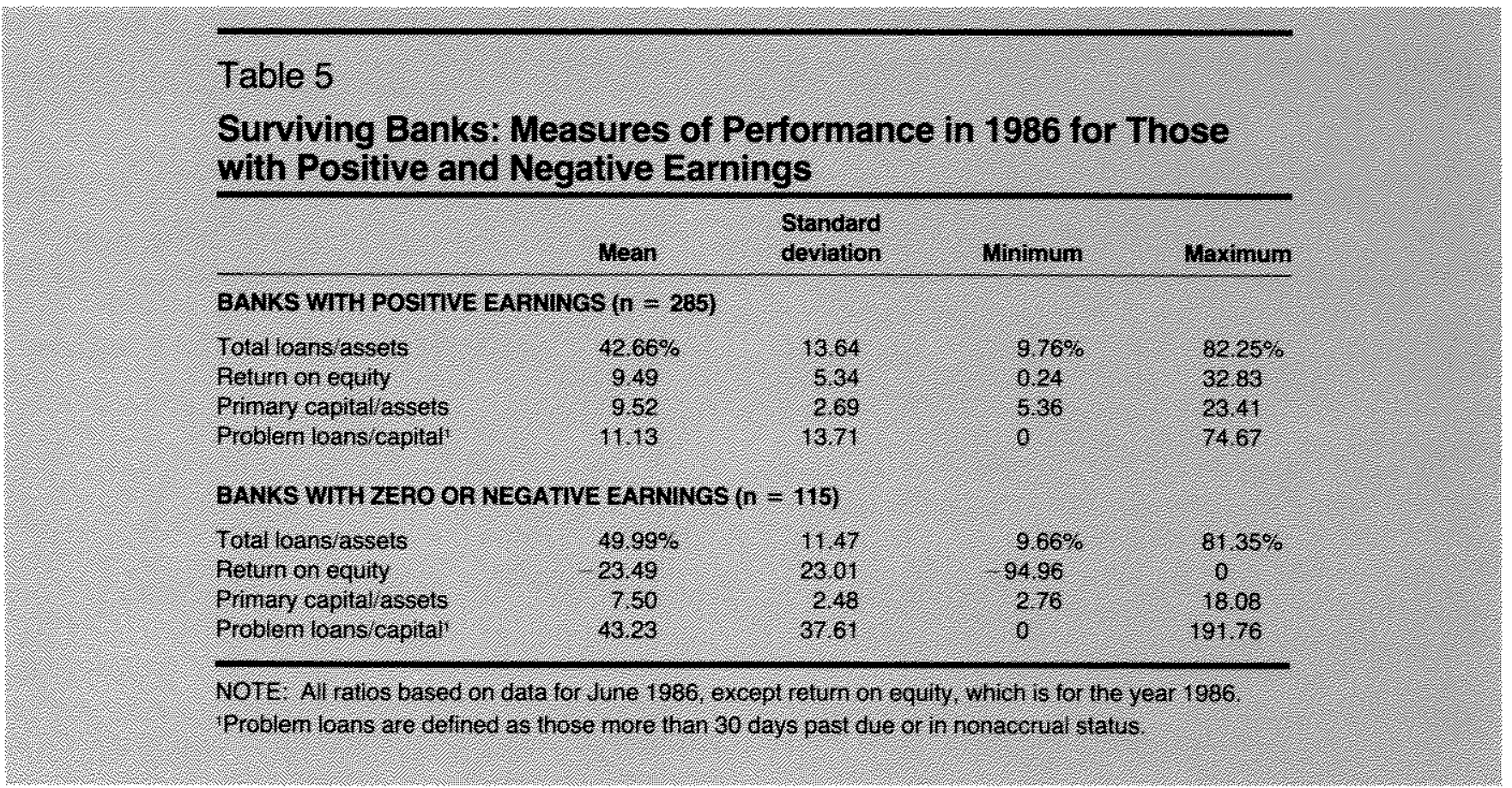

to assets that are statistically significant. Thus, the surviving banks, which had assumed lower risk than the failed banks in 1981 by investing smaller shares of their assets in loans, reduced their exposure to losses on loans even more during the following five years.

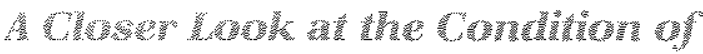

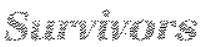

The result in table 4 that surviving banks, on average, had a zero return on equity in 1986 might imply that it is only a matter of time before many of them join the ranks of the 102 failures in the sample. Such a conclusion, however, would be hasty, as the data in table 5 indicate.

If the 400 surviving banks are divided into groups with positive and negative ROE for 1986, we find that the surviving banks fall into the disparate categories of very healthy of very troubled. The 285 banks with positive earnings in 1986 had significantly lower ratios of loans to assets than the banks with negative eam- 
ings. The top portion of table 5 indicates that over 70 percent of the survivors had positive ROEs in 1986 and an average ROE of 9.49 percent; while down from the 1981 ROE average, it nonetheless compares favorably with the 1986 national averages for both agricultural and nonagricultural banks. The banks with positive eamings also have higher capital ratios. Moreover, further significant reductions in earnings and capital ratios appear unlikely, since the ratio of problem loans to primary capital is $\mathbf{1 1}$ percent, on average, for this group of banks. The remaining 115 banks, or 29 percent of the survivors, are in poor financial condition. The bottom portion of table 5 shows ROE to be an average of -23 percent, and these banks are likely to have additional losses; on average, their problem loans exceed 40 percent of their capital.

As a further check on the financial health of the surviving agricultural banks, the 400 solvent banks were grouped on the basis of the ratio of problem loans to capital for June 1986 data. The mean value for this ratio was 20.36 percent. Table 6 indicates that 68 percent of these banks have a problem loan/capital ratio less than 20 percent; for about 12 percent of the banks, problem loans are greater than 50 percent of capital. These figures suggest that, while problem loans are likely to have large, adverse effects on future earnings for some institutions, they do not appear to threaten the solvency of most of the surviving banks.

\section{IMPLICATIONS OF BANK PALLURES FOR FARMERS}

Because farmers typically borrow from banks in their own communities, a final question of interest is whether sound farm banks still remain in counties in which agricultural banks have failed. As of the fourth quarter of 1986, at least one agricultural bank showed positive earnings in 87 of the 96 counties. Moreover, the average ratio of primary capital to total assets was 9.06 percent for these banks. Thus, there remains at least one agricultural bank in sound financial condition in over 90 percent of the counties in which an agricultural bank has failed. ${ }^{8}$

It is important to add, however, that the remaining agricultural banks have relatively low ratios of total

In calculating the number of counties with agricultural banks in December 1986, the investigation is not limited to the 400 surviving banks that were agricultural banks in 1981. Some surviving banks feduced the share of their loans to farmers below 17 percent by 1986 , and others that were agricultural banks in 1986 either were not in business in 1981 or were not classified as agricultural banks at that time.

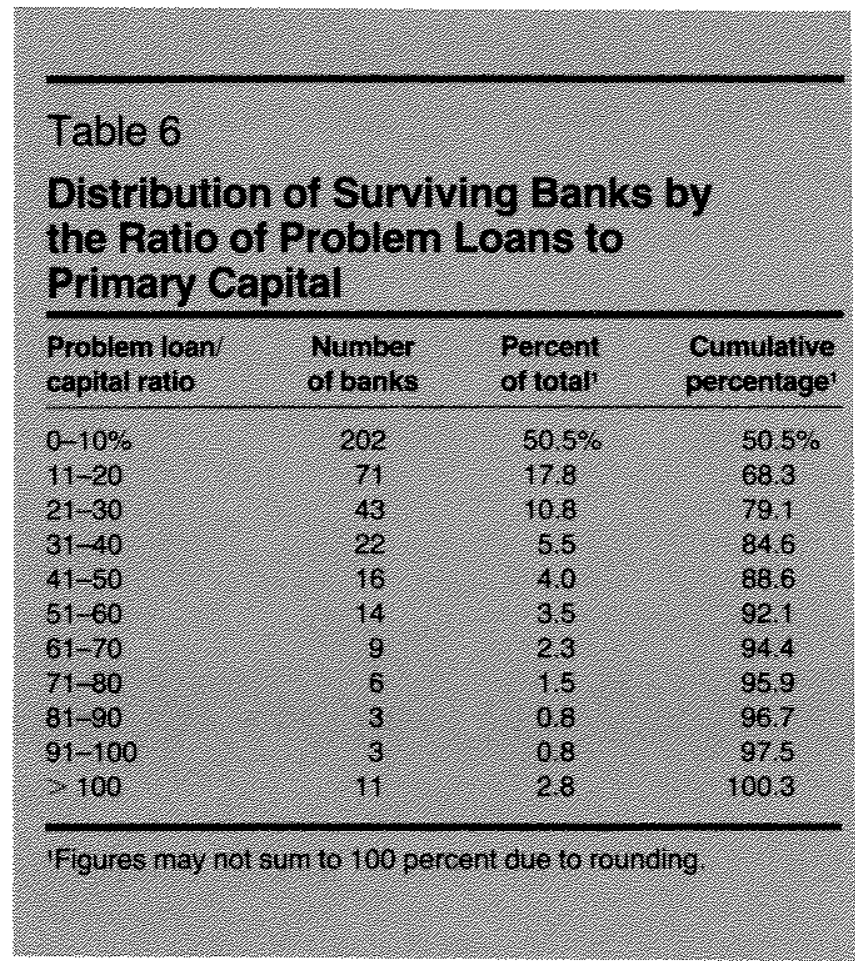

loans to total assets. The healthy agricultural banks in the 87 counties had average ratios of total loans to total assets of 40 percent as of December 31, 1986. Conversely, many banks that had higher ratios of loans to assets have failed.

\section{CONCLUSTONS}

Agricultural banks that failed in recent years were not in weaker condition before the recent years of financial stress in the agricultural sector. In 1981, both the banks that later failed and those that survived had similar profit rates and capital ratios. The banks that failed, however, had invested higher percentages of their assets in loans, in particular agricultural production loans, and lower percentages of their investments in federal government securities. Each difference exposed the banks to a relatively higher risk of losses.

About 70 percent of the surviving agricultural banks remained in relatively strong financial condition in 1986. The other surviving banks reported large losses and large amounts of troubled loans relative to their capital. The banks in relatively strong condition in 1986 also had the lowest ratios of total loans to assets among the surviving banks. Finally, while over 90 percent of the counties in which agricultural banks have failed still are served by at least one agricultural bank in sound financial condition, these remaining banks have relatively low ratios of loans to assets. 


\section{REFERENCES}

Belongia, Michael T. "The Farm Sector in the 1980s: Sudden Col lapse of Steady Downturn?" this Review (November 1986), pp. $17-25$.

Belongia, Michael T, and Kenneth C. Carrato. "The Status of Farm Lenders: An Assessment of Eighth District and National Trends," this Review (October 1985), pp. 17-27.

Belongia, Michael T., and R. Alton Gilbert. "The Farm Credit Crisis: Will It Hurt the Whole Economy?" this Review (December 1985), pp. 5-15.

Bullock, J. Bruce. "Farm Credit Situation: Implications for Agricultural Policy," FAPRi \#4-85, Food and Agricultural Policy Research
Institute (February 1985).

Gilbert, R. Alton, Courtenay C. Stone and Michael E. Trebing. "The New Bank Capital Adequacy Standards," this Review (May 1985), pp. $12-20$.

Holland, A. Steven. "Real Interest Rates: What Accounts for Their Recent Rise?" this Review (December 1984), pp. 18-29.

Melichar, Emanuel. "Agricultural Banks under Siress," Federal Reserve Bulletin (July 1986), pp. 437-48.

"Farm Credit Developments and the Financial Condin tion of Agriculturai Banks," a preliminary report for the National Agricultural Credit Committee, Board of Governors of the Federal Reserve System (March 16, 1987). 